\title{
Multimedia-Based Visual Analysis As A Promotional Media At Raharja Internet Cafe (RIC)
}

\section{Author Notification 6 November 2019}

Final Revised

1 December 2019

\author{
Erick Febriyanto ${ }^{1}$, Qurotul Aini ${ }^{2}$, Afni Afitri ${ }^{3}$
}

1,2,3 University of Raharja, Jl. Jenderal Sudirman No.40 Modern Cikokol Tangerang e-mail: erick@raharja.info, aini@raharia.info, afni@raharia.info
Published

28 December 2019

To cite this document:

Febriyanto, E., Aini, Q., \& Afitri, A. (2019). Multimedia-Based Visual Analysis As A Promotional Media At Raharja Internet Cafe (RIC). Aptisi Transactions On Management (ATM), 4(1), 76-82.

DOI:

https://doi.org/10.33050/atm.v4i1.1116

\begin{abstract}
The development of visual communication media is currently widely used as a means of promotion and information technology. By following the development of information technology today, the delivery of information is no longer presented in the conventional form, but now it has been widely applied in electronic form. One of the results of the development of information technology that can be used as a medium for delivering interesting information can be in the form of Graphic Design such as Online Posters and images uploaded on social media. Raharja Internet Cafe or often called RIC is one of the facilities located at Raharja University. Providing all personal needs Raharja in carrying out lecture activities such as Print, Scan, install iPad, also provides accessories for technological devices such as computers and iPads, besides that RIC also serves computer and iPad services. However, RIC still has problems in presenting information relevant to existing developments. Millennials today tend to get and search for information by accessing social media compared to accessing a website. This is one of the important things that must be applied to Raharja Internet Cafe in conducting socialization and marketing. Therefore, the author was given the opportunity to be able to do the Job Training Lecture (KKP) on Raharja Internet Cafe to apply the knowledge gained in the lecture curriculum. Then the author also gained a lot of knowledge about the world of work that had not previously been obtained in the lecture process. Which in the end, each task and the work that has been done by the author while carrying out the Job Training Lecture (KKP), will be summarized in the Job Training Lecture report.
\end{abstract}

Keywords: Visual Communication Media, Raharja Internet Cafe, and Information Technology

\section{Introduction}

The development of the information technology world that is increasingly growing, accompanied by the development of Industry 4.0 has now demanded business people to be able to convey information quickly, accurately, relevant and reliable. Information must also be able to be presented quickly or up-to-date, then easy to display at any time needed and provide many benefits for users who receive it. Especially in the field of business, where information is a crucial need that can help the seller in making a decision for the progress of his business, both in managerial and operational activities of the company.

Visual electronic media is one of the important things that can be applied as an online promotion media. One of the most frequently accessed media by the current generation or socalled millennial generation is social networking. According to Jamaludin (2015), online promotion is a process of activities carried out by parties (companies) in offering a product or service that is introduced or advertised through online media (internet), so that there is no face-to-face meeting between buyers and sellers. Nowadays social networking or social media has become one of the 
important things in the social life of the younger generation. This can be well utilized by business people in conducting promotions.

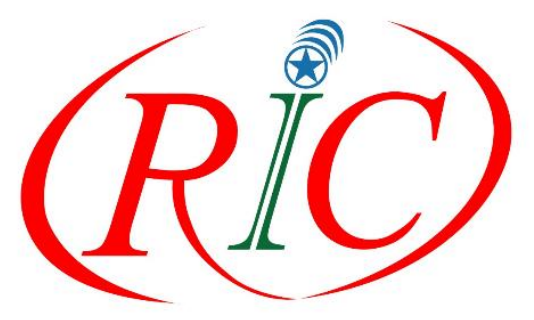

Figure 1. Logo Raharja Internet Cafe

Raharja Internet Cafe or often referred to as RIC is a service place at Raharja University which is devoted to assisting students at Universitas Raharja. RIC facilitates Raharja University students with a comfortable room, printing, photocopying and Student Information System (SIS). This research was conducted so that Raharja Internet Cafe can keep up with the times, by utilizing visual electronic media that is expected to be a means of promotion on social media, which can simultaneously increase student interest in making transactions at Raharja Internet Cafe, and make the design of Visual communication media which is more effective.

\section{Research Method}

In a study needed research methods used to achieve goals and obtain information that is acceptable and accurate that is needed by the author. The following is the design of the research method used in this study:

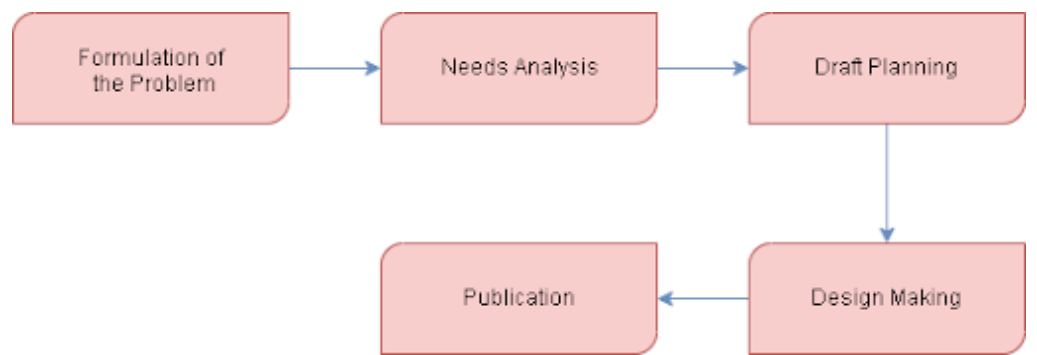

Figure 2. Design of Research Methods

In Figure 2 there are 5 research methods that must be considered, starting from the formulation of the problem where this method is to find out what the deficiencies and problems. Next is the needs analysis phase this stage is carried out to analyze what needs are needed in making an audio visual. Then the concept of planning is carried out to design any concept that will be done in the future. After that the stage of making a design or an overview of the design of a promotional design. And the last is to publish the results of poster designs on social media Raharja Internet Cafe (RIC).

Below there are several literature reviews that are used to identify gaps, avoid repetition, and continue research that has been done before. Some literature reviews are as follows:

1. Research conducted by Muhammad Yusup, Qurotul Aini and Komala Dwi (2016) in Technomedia Journal entitled "Audio Visual Media Using Videoscribe as Presentation of Learning Information in Operating System Classes" which explains that the thing applied is the creation of learning videos as presentation of information and is an operating system classroom learning innovation on the iLearning plus program. After the learning video in the form of audio visual media as a presentation of learning information and makes it easier for students to understand and explore the material that has been delivered.

2. Research conducted by Untung Rahardja et al (2018) in the Journal of Teknoinfo entitled "THE EFFECT OF SERVICE AND FACILITIES IN THE INTERNET CAFE RESULTS OF LECTURE ACTIVITIES IN COLLEGE STUDIES" Raharja. Raharja Internet Cafe is used to help lecture 
activities by facilitating students such as computers, printers and scan machines. Also helps students install or service iPad.

3. Research conducted by Erick Febriyanto et al (2016) on SISFOTENIKA entitled "Motion Graphic Based Video Design for PPDB Harapan Indonesia 1 and 3 Vocational Schools" discussed about producing motion graphic-based profile videos to support the acceptance of new students in the Indonesian Hope Vocational High School 1 and 3, the benefits of the research are to support the acceptance of new students, documentation and promotional media to advance and publish to various social media.

4. Research conducted by llamsyah et al (2019) on Aptisi Transactions on Technopreneurship entitled "The Web-based Raharja Internet Cafe (RIC) Ordering System" The process of buying and selling is very often found in everyday life, starting from merchants selling merchandise to buyers who buy goods. The application of the ordering system on the RIC website, students are now expected to not have to queue to order their needs because they have already ordered the items online by students, so the buying and selling process can be more practical and more efficient, of course.

5. Research conducted by Nita Rimayanti et al (2019) on IT JOURNAL RESEARCH AND DEVELOPMENT entitled "Video Making of the University of Riau Research and Service Institution Profile as Multimedia-Based Promotion Media" This study reviews Promotion is one way to introduce an institution, one of which is the Research and Service Institute (LPPM) of the University of Riau, which requires a media to publicize various activities and research and service activities that have been carried out. For this reason, a profile video needs to be made that can be used to provide information on the performance of LPPM UNRI all this time. Video not only uses a variety of tools and software but by conveying the right message and right in using the camera and various editing purposes will produce the best for media promotion.

6. A study conducted by Evi Septiani et al (2016) in the Public Medical News entitled "The effectiveness of health promotion using audiovisual to changes in perceptions of mothers about sex education for preschoolers" This study explains that this study aims to compare the effect of health promotion through lecture methods with audiovisual aids and leaflets on changing perceptions of mothers about sex education to preschool children.

7. Research conducted by Martono (2018) in Technomedia Journal entitled "Making Video Profiles of the South Tangerang City High School 7 Based on Visual Visual Media as Information and Promotion Media" explains that As the development of developing technology develops as well the more creative, more attractive promotional media, and more innovative, including promotion media in the form of multimedia-based video profiles. It is hoped that by making this profile video the public can more easily obtain all information and have a picture of the state of the school.

8. Research conducted by Maimunah et al (2017) on Semnasteknomedia Online entitled "VISUAL PROTOTYPE DESIGNING IN THE DESIGN PART AS THE INFORMATION AND PROMOTION MEDIA IN PT. SULINDAFIN "This study discusses Visual Design Technology developing along with the times. This forces companies to use quality visual designs and can support company promotions and information and can compete in this globalization era. Therefore PT. SULINDAFIN (Susila Indah Synthetic Fiber Industries) which is engaged in textile yarn requires visual design so that the information and promotions that the company has can be displayed even better.

It can be concluded from the 8 (Eight) Literature Review above that the use of audio visual for promotion on social networks is very big impact. Because the media most often accessed by the current generation or the so-called millennial generation is social networking.

\section{Results and Analysis}

\subsection{Problem Analysis}

Nowadays, with the rapid development of technology, it can be easier for anyone to obtain information from various sources through online and offline media. In the business sector, the dissemination of information is a crucial need that can help the seller in making a decision for the progress of his business. At Raharja Internet Cafe, a breakthrough is needed to do a promotion using the network. By utilizing visual electronic media that is expected to be a means of promoting businesses occupied by using social media.

\subsection{Solution to problem}

After doing research on Raharja Internet Cafe $(R I C)$ regarding promotional analysis using audio visual, the writer can solve the problem by Designing posters as a visual 
communication media used as promotional media that will be applied to Raharja Internet Cafe $(\mathrm{RIC})$. and will publish the results of poster designs on social media.

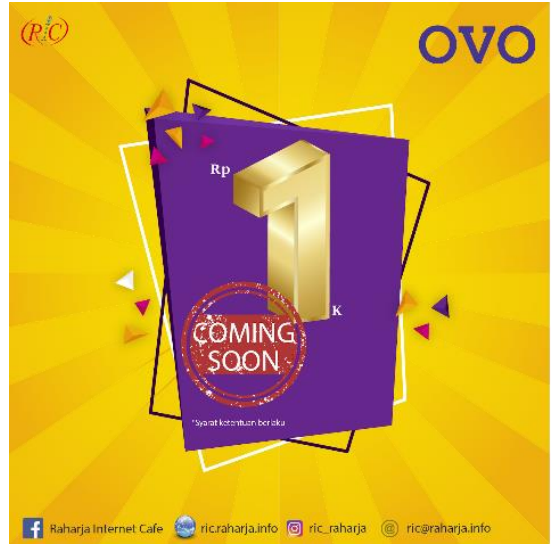

Figure 3. Rp.1K Coming Soon OVO Promo

Figure 3 is a poster design of OVO $1 \mathrm{k}$ promo information which will be at Raharja Internet Cafe (RIC), for the poster size of 640px X 640px which will be posted on RIC social media.

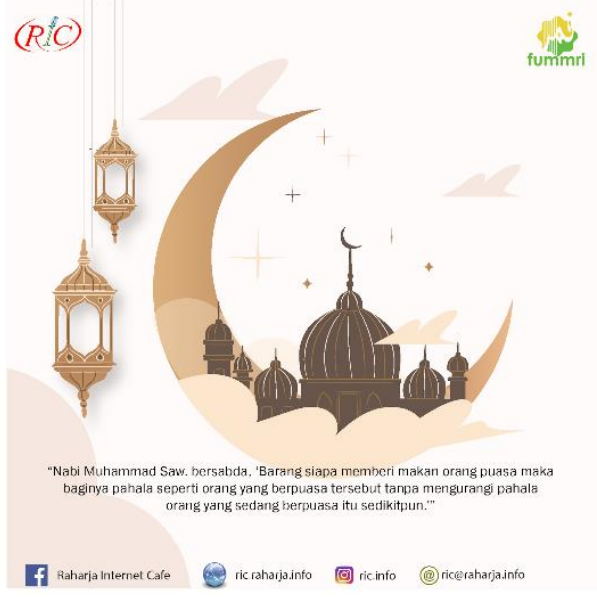

Figure 4 Ramadhan

Figure 4 is a poster design that is a medium to welcome the coming of the holy month of Ramadan, and congratulation fasting to the whole community especially private Raharja, for the poster size is 640px X 640px which will be posted on social RIC Media.

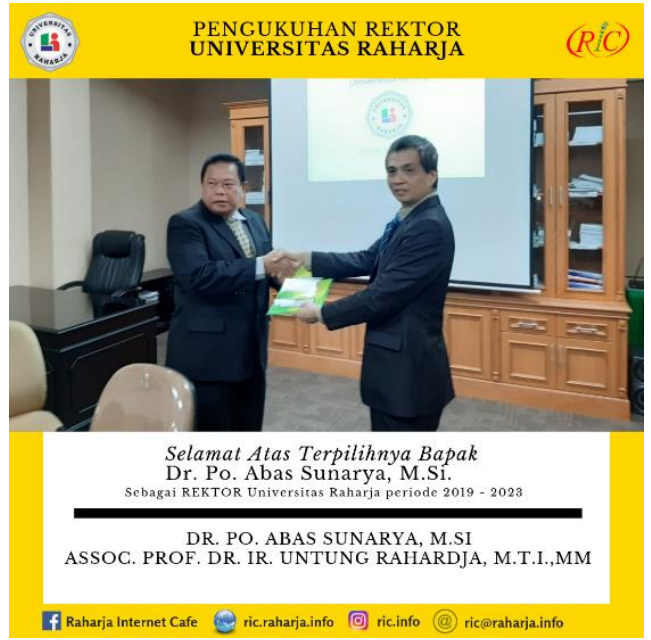

Figure 5. Inauguration of Raharja University Chancellor 
Figure 5 is a poster design to congratulate Raharja University Rector Dr.Po.Abas Sunarya, M.Sc. who took a photo with the chairman of the Foundation, Assoc. Prof.Dr.Ir. Untung Rahardja, M.T.I., MM.

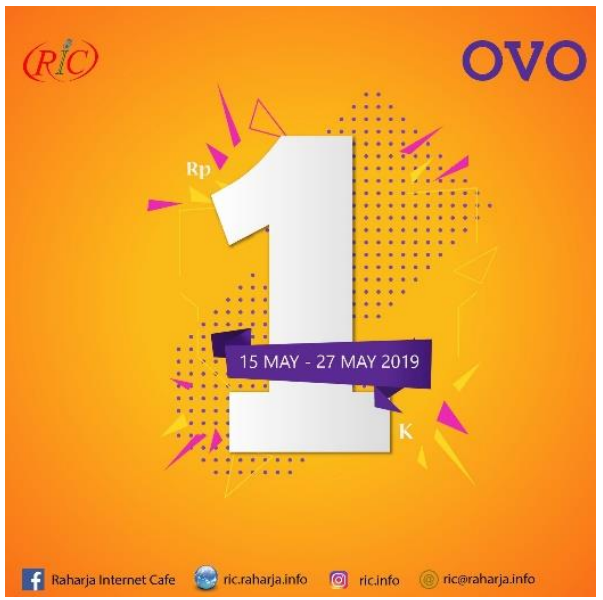

Figure 6. OVO Promo Rp. 1K

Figure 6 is a promotional media such as certain events that took place at Raharja Internet Cafe (RIC) and in the poster gives the event period to be held, namely OVO Promo Rp. $1 \mathrm{~K}$.

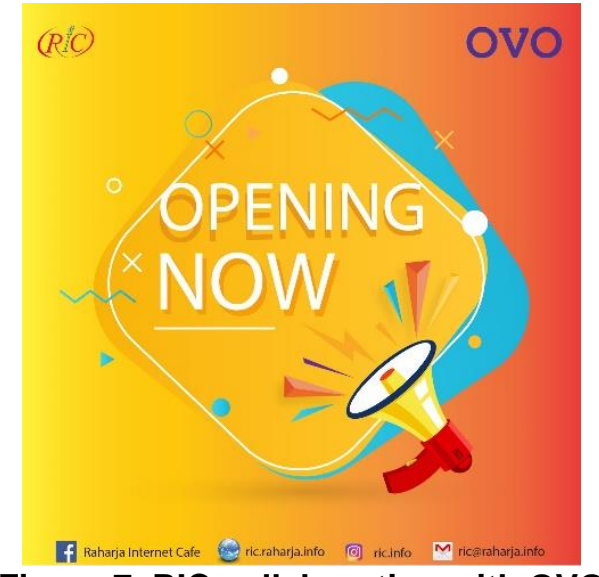

Figure 7. RIC collaboration with OVO

Figure 7 is the poster design image as a medium for delivering information about the activities that take place at Raharja Internet Cafe (RIC) and in the poster provides information regarding the application of transactions carried out at the RIC must use OVO.

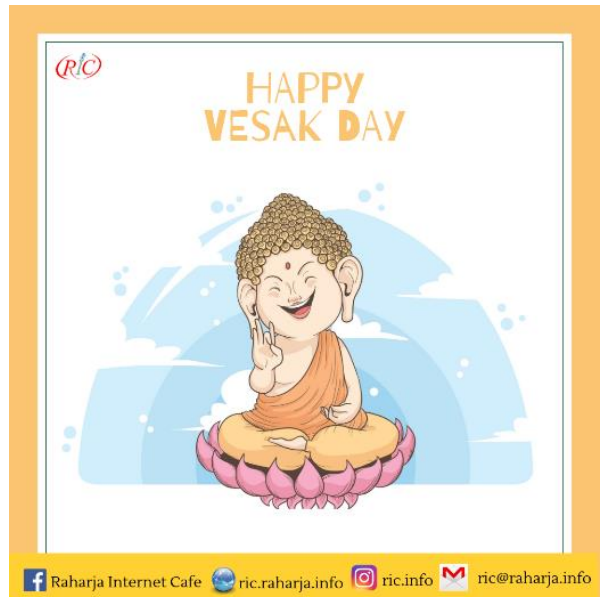

Figure 8. Vesak Day 
Figure 8 is a poster design which is a medium to congratulate all Buddhists who celebrate Vesak Day.

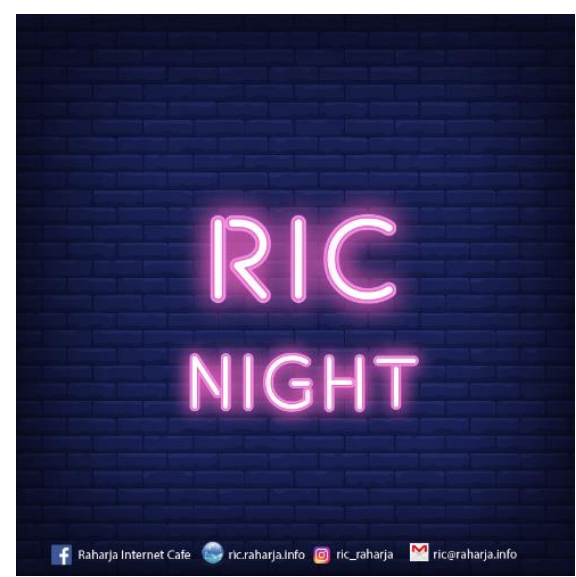

\section{Figure 9. RIC Night}

Figure 9 This poster design is a medium for delivering information about activities taking place at Raharja Internet Cafe (RIC) and in the poster provides information that Raharja Internet Cafe will be open until $9 \mathrm{pm}$.

\section{(RIC) $\begin{gathered}\text { Selamat Hari } \\ \text { Kelahiran Pancasila }\end{gathered}$}
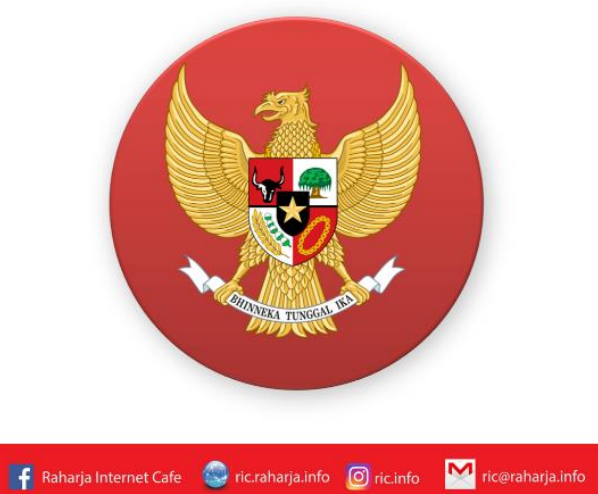

\section{Figure 10. Birth of Pancasila}

Figure 10 This poster design is a medium used to welcome the birthday of Pancasila which falls on June 1.

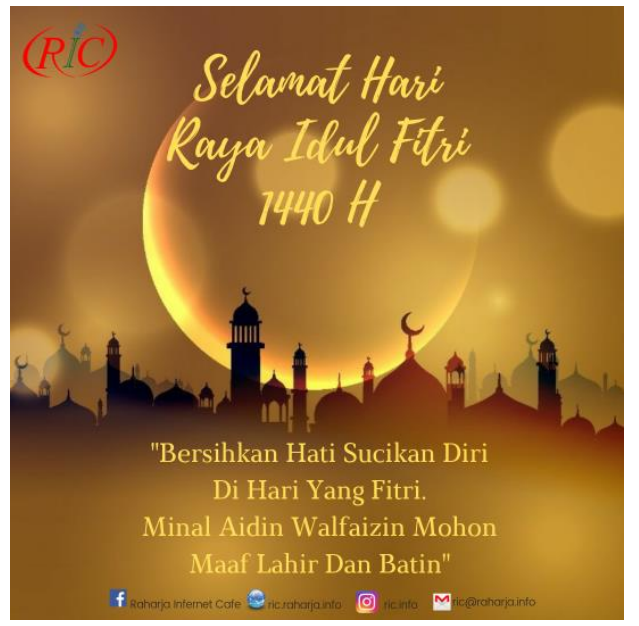

Figure 11. Eid al-Fitri

Figure 11 This poster design is a medium used to welcome the Eid and also to congratulate all Muslims. 


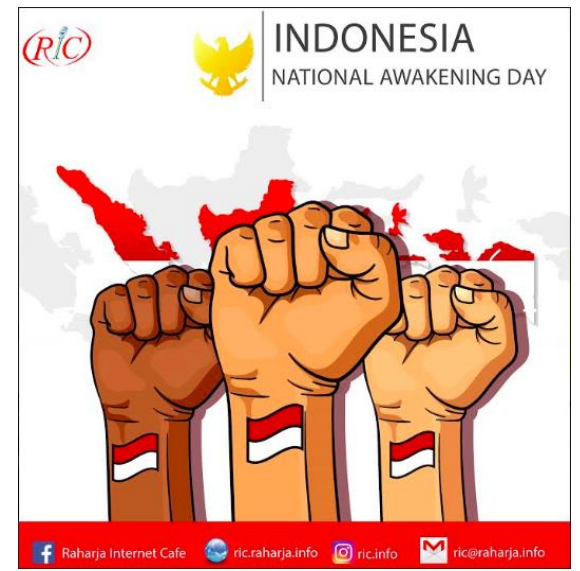

Figure 12. National Awakening Day

Figure 12 This poster design is a medium used to welcome National Awakening Day which falls on May 20th.

\section{Conclusion}

Based on the results of the analysis and formulation of the problems that have been presented in the previous chapter, it can be concluded that the current promotional media at Raharja Internet Cafe still uses simple posters posted around the Raharja Internet Cafe room, so that the delivery of information received by Pribadi Raharja still not comprehensive and still difficult to access anywhere. With the promotion of media using visual communication through social media yatu Instagram makes it easy for the whole community, especially Personal Raharja to get information about Raharja Internet Cafe. Along with the times, nowadays social media has become commonplace even important for millennials. Visual communication media that are delivered with an attractive appearance and keep up with the times of development are very popular among millennials today, such as vintage or color play bright one.

\section{References}

[1] Rimayanti, N., Yulianti, A., Nasution, B., \& Lubis, E. E. (2019). Making Video Profile of the University of Riau Research and Service Institute as a Multimedia-Based Promotion Media. IT JOURNAL RESEARCH AND DEVELOPMENT, 3 (2), 84-95.

[2] Septiani, E., Prawitasari, S., \& Emilia, O. (2016). The effectiveness of health promotion using audiovisual to change the perception of mothers about sex education for preschoolers. Community Medicine News, 32 (11), 421-426.

[3] Febriyanto, E., Handayani, I., \& Bachri, E. W. (2019). Supervisor Rating System in Pessta + S2 Based on Yii Framework as a Media for Entering Postgraduate Student Grades in Higher Education. SATIN-Science and Information Technology, 4 (2), 17-23.

[4] Maimunah, M., Manalu, D. E., \& Kusuma, D. B. (2017). VISUAL PROTOTYPE DESIGN IN DESIGN PART AS INFORMATION AND PROMOTION MEDIA IN PT. SULINDAFIN. ONLINE SEMNASTEKNOMEDIA, 5 (1), 4-6.

[5] Martono, M., Triyono, T., \& Septiani, R. A. (2018). Making Video Profiles of State Senior High School 7 South Tangerang City Based on Audio Visual as Media Information and Promotion. Technomedia Journal, 3 (1), 110-120..

[6] Raharja, U., Harahap, E. P., \& Devi, R. E. C. (2018). The Effect of Services and Facilities on Raharja Internet Cafe Against College Activities in Higher Education. Journal of Teknoinfo, 12 (2), 60-65.

[7] Yusup, M., Aini, Q., \& Pertiwi, K. D. (2016). Audio Visual Media Using Videoscribe as Presentation of Learning Information in Operating System Classes. Technomedia Journal, 1 (1), 126-138.

[8] Nirmalasari, L., Harahap, E. P., \& Faradilla, F. (2018). Implementation of Problem Formulation Management in Improving the Quality of Research in Higher Education. Aptisi Transactions On Management, 2 (1), 20-27.

[9] Ilamsyah, I., Katz, R., \& Fitriani, R. R. (2019). The Web-based Internet Cafe (RIC) Raharja Ordering System. Aptisi Transactions on Technopreneurship, 1 (1), 93-100. 